\title{
ANALISIS KUALITAS PELAYANAN SUB BAGIAN AKADEMIK (SBA) PROGRAM VOKASI UNIVERSITAS INDONESIA
}

\author{
Sancoko $^{1}$ \\ Mohammad Riduansyah ${ }^{2}$ \\ Wahyu Nofiantoro ${ }^{3}$ \\ ${ }^{1,2}$ Laboratorium Administrasi Perkantoran dan Sekretari, Program Vokasi Universitas Indonesia \\ ${ }^{3}$ Laboratorium Keuangan dan Perbankan, Program Vokasi Universitas Indonesia
}

Diterima : 13 November 2015

\section{Abstrak}

Salah satu alat pengukuran tentang kualitas layanan ialah menggunakan metode Serv Quality. Dalam penelitian ini kami mencoba melihat seberapa besar ketimpangan antara persepsi mahasiswa terhadap kinerja pegawai SBA dengan tingkat kepentingan/harapan mahasiswa terhadap pelayanan yang ada dengan menggunakan lima indikator Serv Quality. Aspek yang diteliti ialah, Aspek Keandalan (Reliability), Aspek Ketanggapan (Responsiveness), Aspek Jaminan (Assurance), Aspek Empati(Emphaty), dan Aspek Fisik(Tangibles). SBA menjadi objek penelitian disebabkan mereka menjadi garda terdepan dalam membentuk citra pelayanan di Program Vokasi UI.

Metode yang digunakan dalam penelitian ini adalah metode analisis deskriptif dengan pendekatan kuantitatif, yaitu penelitian yang menggambarkan atau mendeskripsikan kumpulan data atas hasil pengamatan yang telah dilakukan. Kegiatan penelitian ini merupakan lanjutan penelitian sejak semester ganjil 2014/2015 hingga semester ganjil 2015/2016. Populasi dalam penelitian ini ialah mahasiswa Bidang Administrasi Program Vokasi UI. Berdasarkan hasil penelitian dapat disimpulkan masih terdapat gap yang besar terhadap lima dimensi Serv Quality.

Kata kunci; Pelayanan Publik, Kualitas Pelayanan, Matriks Kepentingan-Kinerja.

\begin{abstract}
Measurement tools service quality is using Serv Quality Method. In this study, we tried to see different gap between students' perceptions of employee performance with the level of interest/expectations of students to an existing service using five indicators Serv Quality. Aspects studied is, reliability aspects, responsiveness aspect, assurance Aspects, empathy aspects, and the tangibles aspects. SBA research object because they become the frontline in shaping the image of the ministry in Program vocational UI.

The method used in this research is descriptive analysis method with quantitative approach., ie research that describes a data collection on the observations that have been made. This research activity is a continuation of research since the first semester of 2014/2015 to the first semester of 2015/2016. The population in this study is that students of Administration UI vocational program. Based on the results of this study concluded that there is still a big gap to the five dimensions of Quality Serv.
\end{abstract}

Keyword; Serv Quality, Public Service, Importance-Performance Matrix

\section{PENDAHULUAN}

\section{Latar Belakang}

Dalam proses kegiatan belajar mengajar, mahasiswa akan selalu berinteraksi dengan karyawan SBA Program Vokasi UI. Pegawai Sub Bagian Akademik (SBA) Pegawai SBA menjadi garda terdepan dalam memperlancar kegiatan belajar mengajar sehingga dapat berjalan dengan baik. Program Vokasi UI sebagai organisasi publik yang memberikan pelayanan kepada masyarakat dalam hal ini mahasiswa diharapkan selalu memperbaiki 
kinerjanya, dalam rangka memenuhi kepuasan mahasiswa.

Organisasi yang memberikan pelayanan kepada masyarakat mempunyai ciri pertanggungjawaban publik (public accountability), dimana setiap warga negara mempunyai hak untuk mengevaluasi kualitas pelayanan yang diterima. Kepuasan mahasiswa merupakan faktor penentu keberhasilan bagi setiap organisasi untuk dapat tetap diterima oleh mahasiswa, sehingga pola pelayanan yang diselenggarakan harus disesuaikan dengan kebutuhan pelanggan. Kegiatan pelayanan SBA Program Vokasi UI yang terkait dengan mahasiswa ada tiga bagian yaitu :

1. Bagian Akademik

2. Bagian Kemahasiswaan

3. Bagian Keuangan

Untuk mewujudkan tekad sebagai penyelenggara good governance yang baik. Pihak manajemen perlu mengetahui kekurangan apa saja yang masih memerlukan perbaikan. Sehingga diperlukan improvement para pemangku kepentingan di Program Vokasi UI. Untuk mengukur kualitas pelayanan maka kami menggunakan komponen Serv Quality. Aspek Serv Quality ini terdiri atas lima aspek yaitu, Aspek Keandalan (Reliability), Aspek Ketanggapan (Responsiveness), Aspek Jaminan (Assurance), Aspek Empati (Emphaty), dan Aspek Fisik (Tangibles).

\subsection{Rumusan Masalah}

Pokok permasalahan yang menjadi fokus penelitian yaitu:
1. Apakah terdapat perbedaan antara harapan(tingkat kepentingan) dengan kinerja yang ada terhadap kelima dimensi kualitas pelayanan?

2. Bagaimana kualitas pelayanan sub bagian akademik di Program Vokasi Universitas Indonesia ditinjau dari keandalan (Reliability), ketanggapan (Responsiveness), Jaminan(Assurance), empati (Emphaty), dan fisik (Tangibles)?

3. Bagaimanakah posisi masing-masing dimensi tersebut di diagram matriks menurut tingkat kepentingan (harapan penerima layanan) dan kinerja yang telah dicapai oleh Sub Bagian Akademik Program Vokasi Universitas Indonesia?

\section{Tinjauan Pustaka}

\subsection{Pelayanan}

Pelayanan adalah kegiatan atau urutan kegiatan yang terjadi dalam interaksi langsung antara seseorang dengan orang lain atau mesin secara fisik dan menyediakan kepuasan penerima layanan. Menurut (Sugiarto, 1999) mendefinisikan jasa pelayanan sebagai suatu tindakan yang dilakukan untuk memenuhi keinginan orang lain yang tingkat pemuasannya hanya dapat dirasakan oleh orang yang melayani maupun yang dilayani. Definisi jasa/pelayanan menurut (Kottler, 2000) adalah: A service is any act or performance that one party can offer to another that is essentially intangible and does not result in the ownership of anything. It's production may or may not be tied to physical product. 


\subsection{Kualitas pelayanan}

Menurut (Wijayanto, 2009) kata kualitas memiliki banyak definisi yang berbeda dan bervariasi mulai dari yang konvensional hingga strategis. Definisi konvensional dari kualitas biasanya menggambarkan karakteristik suatu produk seperti kinerja (performance), keandalan (realibility), mudah dalam penggunaan (easy of use) estetika dan sebagainya.

Berdasarkan pengertian kualitas baik yang konvensional maupun yang strategis, oleh (Gasperz, 2005) dinyatakan bahwa sebenarnya kualitas mengacu pada pengertian pokok yaitu kualitas terdiri dari sejumlah keistimewaan produk, baik keistimewaan langsung maupun keistimewaan atraktif yang memenuhi keinginan penerima layanan dan dengan demikian memberikan kepuasan atas penggunaan produk. Kualitas terdiri dari segala sesuatu yang bebas dari kerusakan atau kecurangan. Kualitas pelayanan menurut (Dwiyanto, 2006) dalam Reformasi Pelayanan Publik, adalah pelayanan yang diberikan oleh penerima layanan sesuai dengan standar pelayanan yang telah dibakukan sebagai pedoman dalam pemberian layanan. Standar pelayanan adalah ukuran yang telah ditentukan sebagai suatu pembakuan pelayanan yang baik.

\subsection{Dimensi Kualitas Jasa}

Untuk mengetahui kualitas pelayanan yang diterima oleh penerima layanan, Menurut (A.Parasuraman, A.Zeithmal, \& L.Barry, 1988) memberikan indikator kepuasan penerima layanan yang terletak pada lima dimensi kualitas pelayanan. Kelima dimensi tersebut adalah :

1. Reliability (keandalan)

Yaitu kemampuan untuk memberikan pelayanan yang dijanjikan dengan tepat (accurately) dan kemampuan untuk dipercaya (dependably), terutama memberikan jasa secara tepat waktu (ontime), dengan cara yang sama sesuai dengan jadual yang telah dijanjikan dan tanpa melakukan kesalahan setiap kali.

\section{Responsiveness (daya tanggap)}

Yaitu kemauan atau keinginan para petugas untuk membantu dan memberikan jasa yang dibutuhkan penerima layanan. Membiarkan penerima layanan menunggu, terutama tanpa alasan yang jelas, akan menimbulkan kesan negatif yang tidak seharusnya terjadi. Kecuali jika kesalahan ini ditanggapi dengan cepat, maka bisa menjadi suatu yang berkesan dan menjadi pengalaman yang menyenangkan.

3. Assurance (jaminan)

Meliputi pengetahuan, kemampuan, keramahan, sopan, dan sifat dapat dipercaya dari kontak personel untuk menghilangkan sifat keragu-raguan penerima layanan dan merasa terbebas dari bahaya dan resiko.

\section{Emphaty (empati)}

Meliputi sikap kontak petugas maupun perusahan untuk memahami kebutuhan maupun kesulitan penerima layanan, komunikasi yang baik, perhatian pribadi, kemudahan dalam melakukan komunikasi atau hubungan.

\section{Tangibles (produk-produk fisik)}

Tersedianya fasilitas fisik, perlengkapan, dan sarana komunikasi serta yang lainnya yang dapat dan harus ada dalam proses jasa. Lima 
dimensi kualitas pelayanan tersebut merupakan konsep yang kemudian akan dijabarkan kedalam beberapa variable untuk mengukur tingkat kepuasan

Parasuraman, et.al dalam (Santoso, 2006), telah menyusun suatu model konseptual dari kualitas layanan yang menggambarkan kesenjangan atau ketidaksesuaian antara keinginan dan tingkat kepentingan berbagai pihak yang terlibat dalam penyerahan produk/jasa. Model tersebut dapat dilihat pada Gambar berikut

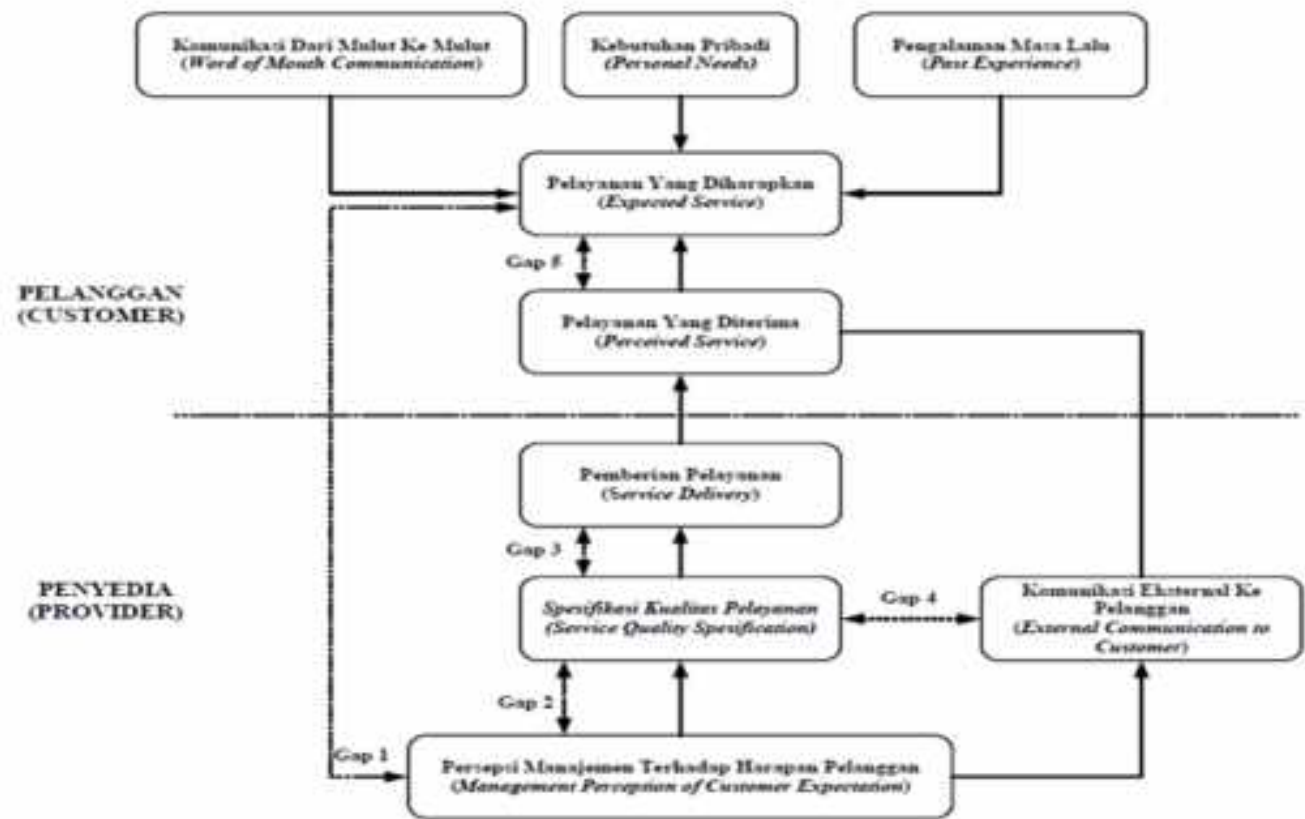

Gambar 1. Model Konseptual Kualitas Pelayanan

Berdasarkan model konseptual di gambar 1, ketidaksesuaian muncul dari lima macam kesenjangan yang dapat dibagi menjadi dua kelompok, yaitu :

1. Satu kesenjangan (gap), yaitu kesenjangan kelima yang bersumber dari sisi penerima layanan (pelanggan).

2. Empat macam kesenjangan (gap), yaitu kesenjangan pertama hingga keempat yang bersumber dari sisi penyedia jasa (manajemen) Lima gap tersebut, adalah:

Gap 1 : Kesenjangan antara persepsi dari pihak penyedia jasa dengan harapan pelanggan. Gap ini menunjukkan perbedaan antara penilaian pelayanan menurut pengguna jasa dengan persepsi manajemen mengenai harapan pengguna jasa, atau dengan kata lain pihak manajemen mempersepsikan ekspektasi pelanggan terhadap kualitas jasa secara tidak akurat.

Gap 2 : Kesenjangan antara persepsi dari pihak penyedia jasa dengan spesifikasi kualitas pelayanan.

Penyebab timbulnya gap ini antara lain :

a.Tidak adanya standar kinerja yang jelas

b.Kesalahan perencanaan atau prosedur perencanaan yang tidak memadai

Gap 3 : Kesenjangan antara spesifikasi 
kualitas pelayanan dengan proses pemberian/penyampaian pelayanan.

Gap ini menunjukkan perbedaan antara spesifikasi kualitas pelayanan dengan penyampaian pelayanan yang diberikan oleh karyawan (contact personnel). Faktor-faktor yang dapat menyebabkan gap ini antara lain:

a. Spesifikasi kualitas terlalu rumit atau terlalu kaku

b. Para karyawan tidak menyepakati spesifikasi tersebut dan karenanya tidak memenuhinya

Gap 4 : Kesenjangan antara peyampaian pelayanan dengan komunikasi eksternal kepada pelanggan.

Gap ini berarti bahwa janji-janji yang disampaikan melalui aktivitas komunikasi pemasaran tidak konsisten dengan jasa yang disampaikan kepada para pelanggan. Hal ini dapat disebabkan beberapa faktor :

a. Perencanaan komunikasi pemasaran tidak terintegrasi dengan operasi jasa

b. Kurangnya koordinasi antara aktivitas pemasaran eksternal dan operasi jasa

Gap 5 : Kesenjangan antara persepsi pelanggan dengan ekspektasi yang dimilikinya.

Jika persepsi dan ekspektasi pelanggan mengenai kualitas pelayanan terbukti sama bahkan persepsi lebih baik dari ekspektasi, maka perusahaan akan mendapat citra dan dampak positif. Namun, bila kualitas pelayanan yang diterima lebih rendah dari yang diharapkan, maka kesenjangan ini akan menimbulkan permasalahan bagi perusahaan.

\subsection{Model Analisis}

Dalam penelitian ini akan memfokuskan kepada kesenjangan yang bersumber dari sisi penerima layanan. Untuk mengetahui kepuasan penerima layanan terhadap pelayanan yang diterimanya dapat dilihat pada gambar 2. Tingkat kepuasan dapat dilihat dari besar kecilnya gap antara penilaian pelaksanaan/kinerja (performance) dan tingkat kepentingan/harapan (importance). Jika gap yang terjadi semakin besar, maka asumsi yang muncul adalah rendahnya kepuasan penerima layanan atau tidak puas terhadap layanan yang diperolehnya. Tetapi sebaliknya apabila kesenjangan yang terjadi atau nol mencerminkan kepuasan optimal penerima layanan atas layanan yang diterimanya. Selanjutnya untuk mengetahui pada atribut-atribut mana dari dimensi kualitas pelayanan tersebut maka akan dilakukan pemetaan ke dalam diagram kartesius. 


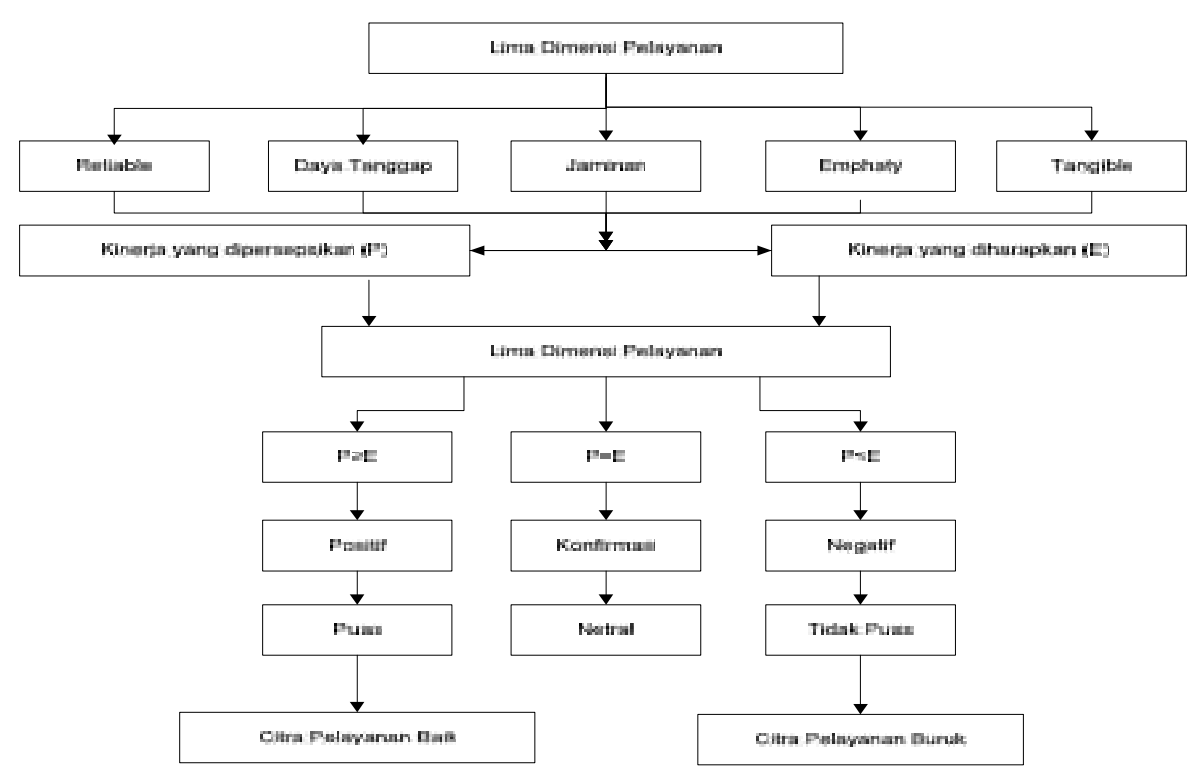

Gambar 1. Model Analisis Gap 5 (Yustisianto, 2007)

\subsection{Metodologi Penelitian}

Metode yang digunakan dalam penelitian ini adalah metode analisis deskriptif dengan pendekatan kuantitatif, yaitu penelitian yang menggambarkan atau mendeskripsikan kumpulan data atau hasil pengamatan yang telah dilakukan. Lokasi Penelitian ini bertempat di Sub Bagian Akademik (SBA/ Sekretariat) Program Vokasi UI. Waktu Penelitian ini dilakukan pada semester genap dan semester ganjil tahun ajaran 2014/2015.

Teknik pengumpulan data penelitian mempunyai tujuan untuk mendapatkan atau mengumpukan data/informasi yang dapat menjelaskan dan atau menjawab permasalahan penelitian secara objektif. Untuk mengumpulkan data serta informasi yang digunakan oleh penulis menggunakan kuisioner. Menurut (McClave, Benson, \& Sincich, 2011) populasi ialah sekumpulan unit (biasanya orang, objek,transaksi atau kejadian yang ingin dipelajari). Sedangkan sampel ialah subset unit-unit dari suatu Populasi. Populasi dalam penelitian ini adalah seluruh mahasiswa bidang Administrasi yang menjadi pengguna layanan di Sub Bagian Akademik (SBA)/Sekretariat Program Vokasi UI.

Dengan mempertimbangkan populasi dan mengingat keterbatasan waktu yang ada, maka dalam penelitian ini menggunakan teknik Non Probabilty sampling. Menurut (Sugiyono, 2009) Non Probabilty sampling ialah teknik pengambilan sampel yang tidak memberi peluang/kesempatan sama bagi setiap unsur atau anggota populasi untuk dipilih menjadi sampel, khususnya purposive sampling. Purposive sampling ialah cara memilih sampel dari suatu populasi didasarkan pada informasi yang tersedia, sehingga perwakilannya terhadap populasi dapat dipertanggungjawabkan. Dalam penelitian ini besar sampel yang diambil dihitung 
dengan menggunakan rumus Slovin (Prasetyo \& Jannah, 2005), yaitu :

$$
\mathrm{n}=\frac{\mathrm{N}}{1+\mathrm{N}(\mathrm{e})^{2}}
$$

$\mathrm{n}=$ besaran sampel

$\mathrm{N}=$ besaran populasi

$\mathrm{E}=$ Batas toleransi kesalahan (persen ketidaktelitian karena kesalahan penarikan sampel)

Untuk penelitian ini penulis menetapkan batas toleransi kesalahan sebesar 5 persen. Sehingga besar sampel yang harus diambil sebanyak 314 sampel dari populasi mahasiswa bidang administrasi(2012-2014) sebanyak 1143 orang.

\subsection{Uji Validitas dan Reliabilitas}

\subsubsection{Uji Validitas}

Menurut (Umar, 2002) validitas ialah sejauh mana suatu alat ukur dapat mengukur sesuai dengan apa yang ingin diukur. Hubungan antara suatu pengukuran dengan suatu kriteria biasanya digambarkan dengan suatu korelasi, yang disebut dengan koefisien validitas. Suatu alat ukur dapat dikatakan berhasil menjalankan fungsi ukurnya apabila menjalankan alat ukurnya dengan cermat dan akurat.

\subsubsection{Uji Reliabilitas}

Menurut Harrison dalam (Zulganef, 2006) reliabilitas ialah ukuran yang menunjukkan bahwa alat ukur yang digunakan dalam penelitian mempunyai keandalan sebagai alat ukur, diantaranya di ukur melalui konsistensi hasil pengukuran dari waktu ke waktu jika fenomena yang diukur tidak berubah. Tinggi reliabilitas secara empiris ditunjukkan oleh suatu angka yang disebut koefisien reliabilitas. Secara teoritis besarnya koefisien reliabilitas verkisar antara $0,00-1,00$. Selain itu, walaupun koefisien dapat bernada positif atau negatif, namun dalam reliabilitas, koefisien yang besarnya kurang dari nol tidak ada artinya karena interpretasi reliabilitas selalu mengacu kepada koefisien yang positif.

Tabel 1. Kriteria Realibilitas

\begin{tabular}{|l|l|}
\hline Koefisien Korelasi & Kriteria Reliabilitas \\
\hline $0,81<\mathrm{r} \leq 1,00$ & Sangat tinggi \\
\hline $0,61<\mathrm{r} \leq 0,80$ & Tinggi \\
\hline $0,41<\mathrm{r} \leq 0,60$ & Cukup \\
\hline $0,21<\mathrm{r} \leq 0,40$ & Rendah \\
\hline $0,00<\mathrm{r} \leq 0,20$ & Sangat rendah \\
\hline \multicolumn{2}{|c|}{ (Arikunto, 2003) }
\end{tabular}

Berdasarkan kriteria di atas terlihat bahwa butir yang baik adalah butir yang memiliki koefisien korelasi diatas 0,61. Selain uji validitas, instrumen yang digunakan sebagai alat untuk mengumpulkan data responden juga harus memiliki keandalan yang baik

\subsection{Teknik Analisis Data}

Pada penelitian kualitas pelayanan SBA, penulis menggunakan skala likert. Dimana menurut (Sugiyono, 2009) skala likert ialah skala yang digunakan untuk mengukur sikap, pendapat, dan persepsi seseorang atau sekelompok orang tentang fenomena sosial. Variabel penelitian yang diukur dengan skala likert ini, dijabarkan kedalam indikator variabel yang kemudian 
dijadikan titik tolak penyusunan butir-butir instrumen. Instrumen penelitian yang menggunakan skala likert dibuat dalam bentuk multiple choice.

Pada penelitian ini instrument servqual dibagi menjadi dua bagian. Pertama pertanyaan untuk mengukur persepsi penerima layanan. Kedua untuk mengukur tingkat harapan/kepentingan penerima layanan. Selanjutnya untuk menghitung perbedaan tersebut digunakan formula:

\section{Skor Servqual $=$ Skor Persepsi - Skor Harapan}

Metode ini digambarkan melalui distribusi frekuensi data dari masing-masing dimensi yang dipilih oleh penerima layanan, sehingga hasil penelitian akan mencerminkan gambaran umum sampel yang diteliti. Metode itu juga untuk menjelaskan bagaimana penilaian responden terhadap pelaksanaan kinerja atau performance dan tingkat kepentingan/harapan (importance) terhadap dimensi kualitas pelayanan. Setelah memberikan pembobotan terhadap gap antara kepentingan dengan kinerja, maka dilakukan analisa menggunakan "Importance-Performance Analysis”. Menurut Tjiptono dalam (Ong \& Pambudi, 2014) teknik ini dikemukakan pertama kali oleh Martilla dan James pada tahun 1977 dalam artikel mereka "ImportancePerformance Analysis" yang dipublikasikan di Journal of Marketing. Pada teknik ini, responden diminta untuk menilai tingkat kepentingan dan kinerja perusahaan, kemudian nilai rata-rata tingkat kepentingan dan kinerja tersebut dianalisis pada Importance-Performance Matrix, yang mana sumbu x mewakili persepsi sedangkan sumbu y mewakili harapan. Gambarnya adalah sebagai berikut:

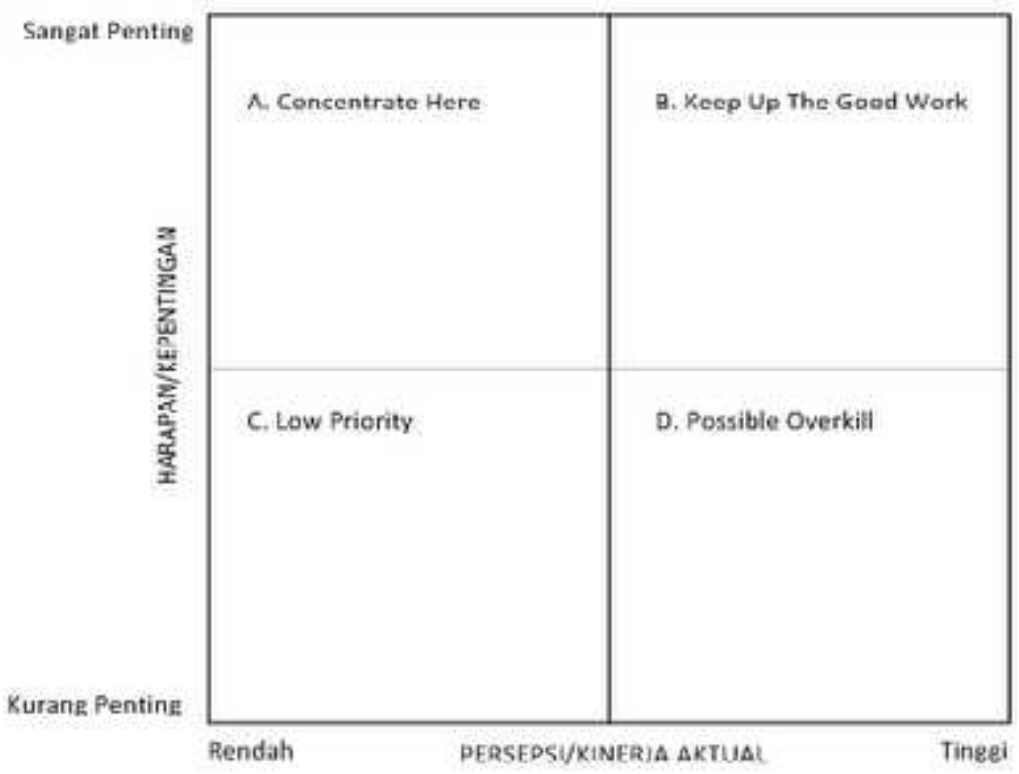

Gambar 3. Importance-Performance Matrix 
Adapun interpretasi dari kuadran tersebuat adalah sebagai berikut:

\section{A. Prioritas Utama (Concentrate Here)}

Pada kuadaran ini terdapat faktor-faktor yang dianggap penting dan atau diharapkan konsumen akan tetapi kinerja perusahaan dinilai belum memuaskan sehingga pihak perusahaan perlu berkonsentrasi untuk mengalokasikan sumber dayanya guna meningkatkan performa yang masuk pada kuadran ini.

B. Pertahankan Prestasi (Keep Up The Good Work)

Pada kuadaran ini terdapat faktor-faktor yang dianggap penting dan diharapkan sebagai faktor penunjang kepuasan konsumen sehingga perusahaan wajib untuk mempertahankan prestasi kinerja tersebut.

C. Prioritas Rendah (Low Priority)

Pada kuadaran ini terdapat faktor-faktor yang dianggap mempunyai tingkat persepsi atau kinerja aktual yang rendah dan tidak terlalu penting dan atau tidak terlalu diharapkan oleh konsumen sehingga perusahaan tidak perlu memprioritaskan atau memberikan perhatian lebih pada faktor-faktor tersebut.

\section{Berlebihan (Possibly Overkill)}

Pada kuadaran ini terdapat faktor-faktor yang dianggap tidak terlalu penting dan tidak terlalu diharapkan oleh pelanggan sehingga perusahaan lebih baik mengalokasikan sumber daya yang terkait pada faktor tersebut kepada factor lain yang lebih memiliki tingkat prioritas lebih tinggi.

Analisis kualitas pelayanan terkait dengan kepentingan penerima layanan diukur dengan kaitannya apa yang seharusnya dikerjakan oleh instansi pemberi layanan agar menghasilkan jasa yang berkualitas tinggi, maka digunakan analisis Importance dan Performance Matrix. Analisis ini juga digunakan untuk meneliti faktor-faktor apa saja yang perlu ditingkatkan terhadap kualitas pelayanan yang diterima oleh penerima layanan.

\section{Analisis dan Pembahasan}

\subsubsection{Karakteristik Responden}

Jumlah responden layanan Sub Bagian Akademik(SBA) yang menjadi sampel penelitian ini adalah 361 orang. Responden yang menerima layanan tersebut adalah mahasiswa bidang Administrasi yang menerima layanan Sub Bagian Akademik(SBA) di Program Vokasi UI. Penerima layanan ini dikualifikasikan berdasarkan tiap Angkatan, Program Studi dan Jenis Kelamin.

Berdasarkan hasil riset dapat diketahui data responden angkatan 2012- 2014. Responden Angkatan 2012 sebanyak 168 orang atau $47 \%$ dari total responden. Responden Angkatan 2013 sebanyak 94 orang atau $26 \%$ dari total responden. Sedangkan Angkatan 2014 sebanyak 99 orang atau $27 \%$ dari total responden.

\subsubsection{Jumlah Mahasiswa Tiap program studi}

Berdasarkan hasil riset dapat diketahui tentang data responden mahasiswa bidang administrasi. Reponden yang berasal dari Program Studi Adm Perkantoran dan 
Sekretari sebanyak 138 orang atau $38 \%$ dari total responden. Reponden yang berasal dari Program Studi Adm Perpajakan sebanyak 91 orang atau $25 \%$ dari total responden. Reponden yang berasal dari Program Studi Adm Perbankan sebanyak 77 orang atau $22 \%$ dari total responden. Sementara sebanyak 55 orang atau $15 \%$ dari total responden berasal dari Program Studi Adm. Asuransi dan Aktuaria.

\subsubsection{Jumlah responden berdasar jenis kelamin}

Berdasarkan hasil riset dapat diketahui bahwa jenis kelamin perempuan lebih banyak dari jenis kelamin laki-laki pada 361 sampel responden. Jenis kelamin perempuan adalah 288 orang atau $80 \%$ dari total responden, sementara responden lakilaki adalah 73 orang atau $20 \%$ dari total responden.

\subsection{Hasil Penelitian}

\subsubsection{Hasil Uji Validitas}

Hasil uji validitas instrumen, baik faktor maupun butir pertanyaan ini secara rinci dapat dilihat pada bagian berikut ini:

Tabel 2. Hasil Uji Validitas Faktor

\begin{tabular}{|l|l|l|l|}
\hline No & $\begin{array}{l}\text { Butir-butir } \\
\text { Dimensi }\end{array}$ & Nilai & Keputusan \\
\hline 1 & Reliable & 0,685 & valid \\
\hline 2 & Responsive & 0,695 & valid \\
\hline 3 & Assurance & 0,729 & valid \\
\hline 4 & Emphati & 0,799 & valid \\
\hline 5 & Tangible & 0,751 & valid \\
\hline
\end{tabular}

Sumber : diolah
Dari tabel di atas menunjukkan bahwa faktor-faktor yang terdapat dalam instrumen penelitian memiliki tingkat validitas yang sangat tinggi. Hal ini terlihat dari nilai rxy di atas $r 5 \%=0,113$. Dengan demikian, berdasarkan uji validitas instrumen ini menunjukkan bahwa faktor-faktor yang membangun kuesioner sangat valid untuk digunakan sebagai instrumen penelitian

\subsubsection{Uji Reliabilitas.}

Hasil uji reliabilitas instrumen dari faktor-faktor yang dianalisis dapat dilihat secara keseluruhan pada tabel berikut ini:

Tabel 3. Hasil Uji Reliability

\begin{tabular}{|l|l|l|l|}
\hline No & $\begin{array}{l}\text { Butir-butir } \\
\text { Dimensi }\end{array}$ & Nilai & Keputusan \\
\hline 1 & Reliability & 0.783 & reliable \\
\hline 2 & Responsive & 0.811 & reliable \\
\hline 3 & Assurance & 0.800 & reliable \\
\hline 4 & Emphaty & 0.873 & reliable \\
\hline 5 & Tangible & 0.816 & reliable \\
\hline
\end{tabular}

Sumber : diolah

Berdasarkan hasil uji reliabilitas yang disajikan pada tabel di atas menunjukkan keseluruhan faktor yang digunakan dalam instrumen pernyataan bersifat reliabel.

\subsubsection{Analisis Dimensi Kualitas Pelayanan}

Untuk melihat apakah terdapat kesenjangan antara persepsi terhadap tingkat kinerja serta tingkat kepentingan, maka diginakan formula berikut ini :

Skor Servqual $=$ Skor Persepsi $($ Kinerja $)-$ Skor Kepentingan 
Tabel 4. Perhitungan Selisih Kinerja Dengan Skor Kepentingan

\begin{tabular}{|c|c|c|c|}
\hline Komponen & $\begin{array}{l}\text { Tingkat } \\
\text { Kinerja }\end{array}$ & $\begin{array}{l}\text { Tingkat } \\
\text { Kepentingan }\end{array}$ & $\begin{array}{l}\text { Skor } \\
\text { Serv }\end{array}$ \\
\hline $\begin{array}{l}\text { O1.Prosedur pelayanan yang ada di SBA mudah dan } \\
\text { tidak berbelit-belit. }\end{array}$ & 1101 & 1417 & -316 \\
\hline O2. Petugas memenuhi pelayanan yang telah dijanjikan. & 1154 & 1458 & -304 \\
\hline $\begin{array}{l}\text { O3. Mahasiswa mendapatkan sesuatu yang dibutuhkan } \\
\text { dengan cepat. }\end{array}$ & 1039 & 1445 & -406 \\
\hline $\begin{array}{l}\text { O4. Mahasiswa mendapatkan kemudahan dalam } \\
\text { memperoleh akses dan informasi pelayanan. }\end{array}$ & 1113 & 1476 & -363 \\
\hline $\begin{array}{l}\text { 05. Petugas cepat tanggap memahami kebutuhan dan } \\
\text { permintaan Mahasiswa. }\end{array}$ & 1060 & 1440 & -380 \\
\hline $\begin{array}{l}\text { O6. Petugas segera bertindak menyelesaikan kebutuhan } \\
\text { dan permintaan mahasiswa. }\end{array}$ & 1090 & 1448 & -358 \\
\hline $\begin{array}{l}\text { 07. Petugas memberikan informasi yang jelas dan } \\
\text { mudah dimengerti atas pertanyaan Mahasiswa. }\end{array}$ & 1152 & 1470 & -318 \\
\hline $\begin{array}{l}\text { O8. Kerelaan dan sikap tulus dari petugas untuk } \\
\text { membantu Mahasiswa. }\end{array}$ & 1027 & 1444 & -417 \\
\hline $\begin{array}{l}\text { 09. Petugas cukup berpengetahuan dan terampil dalam } \\
\text { melayani Mahasiswa }\end{array}$ & 1190 & 1462 & -272 \\
\hline $\begin{array}{l}\text { 10. Petugas SBA memberikan pelayanan secara } \\
\text { menyeluruh dan tuntas. }\end{array}$ & 1151 & 1448 & -297 \\
\hline 11. Petugas SBA dapat berkomunikasi secara efektif. & 1119 & 1451 & -332 \\
\hline $\begin{array}{l}\text { 12. Petugas SBA percaya diri pada saat memberikan } \\
\text { pelayanan. }\end{array}$ & 1254 & 1447 & -193 \\
\hline $\begin{array}{l}\text { 13. Petugas mendengarkan dengan seksama keluhan- } \\
\text { keluhan atau permintaan Mahasiswa. }\end{array}$ & 1036 & 1436 & -400 \\
\hline 14. Petugas mengerti kebutuhan Mahasiswa secara rinci & 1072 & 1451 & -379 \\
\hline $\begin{array}{l}\text { 15. Petugas memberlakukan setiap Mahasiswa penerima } \\
\text { layanan dengan simpati dan manusiawi }\end{array}$ & 1084 & 1469 & -385 \\
\hline $\begin{array}{l}\text { 16. Mahasiswa merasa nyaman dalam mengeluarkan } \\
\text { pendapat tentang kebutuhan terhadap petugas } \\
\text { layanan }\end{array}$ & 1029 & 1450 & -421 \\
\hline $\begin{array}{l}\text { 17. Petugas SBA memiliki penampilan yang bersih dan } \\
\text { rapih }\end{array}$ & 1284 & 1488 & -204 \\
\hline
\end{tabular}




\begin{tabular}{|l|l|l|l|}
\hline \multicolumn{1}{|c|}{ Komponen } & $\begin{array}{l}\text { Tingkat } \\
\text { Kinerja }\end{array}$ & $\begin{array}{l}\text { Tingkat } \\
\text { Kepentingan }\end{array}$ & $\begin{array}{l}\text { Skor } \\
\text { Serv }\end{array}$ \\
\hline $\begin{array}{c}\text { 18. Ruang Pelayanan SBA terlihat bersih dan nyaman } \\
\text { memudahkan pelayanan di SBA. }\end{array}$ & 1290 & 1518 & -228 \\
\hline $\begin{array}{c}\text { 19. Peralatan tersedia lengkap dan modern untuk } \\
\text { yang tersedia sebagai pedoman dalam permintaan } \\
\text { pelayanan. }\end{array}$ & 1019 & 1411 & -286 \\
\hline
\end{tabular}

Sumber : Data Primer diolah tahun 2015

Berdasarkan perhitungan pada tabel diatas. dapat diketahui tingkat kesenjangan yang terjadi. Jika hasil perhitungan skor servqual makin negatif menunjukkan bahwa kualitas pelayanan dinilai buruk oleh mahasiswa. Sebaliknya jika hasil perhitungan skor servqual makin postif berarti kualitas pelayanan semakin baik dirasakan oleh mahasiswa. Dari data diatas menunjukkan hasil yang negatif maka dapat disimpulkan terjadi kesenjangan (gap) yang terjadi antara persepsi penerima layanan (kenyataan) dan harapan penerima layanan, mahasiswa menganggap pelayanan di SBA buruk.

\subsubsection{Analisis Pemetaan Dimensi Kualitas} Pelayanan Dengan Menggunakan Diagram

\section{Kartesius}

Untuk mengetahui pemetaan dari serv quality di Sub Bagian Akademik Program Vokasi UI dapat dilihat table di bawah ini

Tabel 5. Skor Rata-Rata Kinerja dan Harapan

\begin{tabular}{|c|l|l|l|}
\hline \multicolumn{1}{|c|}{ Komponen } & Rata-rata & $\begin{array}{l}\text { Rata-Rata } \\
\text { Kepentingan }\end{array}$ & Kuadran \\
\hline $\begin{array}{c}\text { O1.Prosedur pelayanan yang ada di SBA } \\
\text { mudah dan tidak berbelit-belit }\end{array}$ & 3.05 & 3.93 & $\mathrm{C}$ \\
\hline $\begin{array}{c}\text { O2. Petugas memenuhi pelayanan yang telah } \\
\text { dijanjikan }\end{array}$ & 3.20 & 4.04 & $\mathrm{~B}$ \\
\hline $\begin{array}{c}\text { 03. Mahasiswa mendapatkan sesuatu yang } \\
\text { dibutuhkan dengan cepat. }\end{array}$ & 2.88 & 4.00 & $\mathrm{C}$ \\
\hline $\begin{array}{c}\text { O4. Mahasiswa mendapatkan kemudahan } \\
\text { dalam memperoleh akses dan informasi } \\
\text { pelayanan. }\end{array}$ & 3.08 & 4.09 & $\mathrm{~A}$ \\
\hline $\begin{array}{c}\text { 05. Petugas cepat tanggap memahami } \\
\text { kebutuhan dan permintaan Mahasiswa }\end{array}$ & 2.94 & 3.99 & $\mathrm{C}$ \\
\hline
\end{tabular}




\begin{tabular}{|c|c|c|c|}
\hline Komponen & $\begin{array}{l}\text { Rata-rata } \\
\text { Kenyataan }\end{array}$ & $\begin{array}{l}\text { Rata-Rata } \\
\text { Kepentingan }\end{array}$ & Kuadran \\
\hline $\begin{array}{l}\text { 06. Petugas segera bertindak menyelesaikan } \\
\text { kebutuhan dan permintaan mahasiswa }\end{array}$ & 3.02 & 4.01 & $\mathrm{C}$ \\
\hline $\begin{array}{l}\text { 07. Petugas memberikan informasi yang } \\
\text { jelas dan mudah dimengerti atas } \\
\text { pertanyaan Mahasiswa }\end{array}$ & 3.19 & 4.07 & B \\
\hline $\begin{array}{l}\text { 08. Kerelaan dan sikap tulus dari petugas } \\
\text { untuk membantu Mahasiswa }\end{array}$ & 2.84 & 4.00 & $\mathrm{C}$ \\
\hline $\begin{array}{l}\text { 09. Petugas cukup berpengetahuan dan } \\
\text { terampil dalam melayani Mahasiswa }\end{array}$ & 3.30 & 4.05 & $\mathrm{~B}$ \\
\hline $\begin{array}{l}\text { 10. Petugas SBA memberikan pelayanan } \\
\text { secara menyeluruh dan tuntas. }\end{array}$ & 3.19 & 4.01 & $\mathrm{D}$ \\
\hline $\begin{array}{l}\text { 11. Petugas SBA dapat berkomunikasi secara } \\
\text { efektif. }\end{array}$ & 3.10 & 4.02 & $\mathrm{C}$ \\
\hline $\begin{array}{l}\text { 12. Petugas SBA percaya diri pada saat } \\
\text { memberikan pelayanan. }\end{array}$ & 3.47 & 4.01 & $\mathrm{D}$ \\
\hline $\begin{array}{l}\text { 13. Petugas mendengarkan dengan seksama } \\
\text { keluhan-keluhan atau permintaan } \\
\text { Mahasiswa. }\end{array}$ & 2.87 & 3.98 & $\mathrm{C}$ \\
\hline $\begin{array}{l}\text { 14. Petugas mengerti kebutuhan Mahasiswa } \\
\text { secara rinci. }\end{array}$ & 2.97 & 4.02 & $\mathrm{C}$ \\
\hline $\begin{array}{l}\text { 15. Petugas memberlakukan setiap } \\
\text { Mahasiswa penerima layanan dengan } \\
\text { simpati dan manusiawi. }\end{array}$ & 3.00 & 4.07 & $\mathrm{~A}$ \\
\hline $\begin{array}{l}\text { 16. Mahasiswa merasa nyaman dalam } \\
\text { mengeluarkan pendapat tentang } \\
\text { kebutuhan terhadap petugas layanan. }\end{array}$ & 2.85 & 4.02 & $\mathrm{C}$ \\
\hline $\begin{array}{l}\text { 17. Petugas SBA memiliki penampilan yang } \\
\text { bersih dan rapih. }\end{array}$ & 3.56 & 4.12 & $\mathrm{~B}$ \\
\hline $\begin{array}{l}\text { 18. Ruang Pelayanan SBA terlihat bersih } \\
\text { dan nyaman. }\end{array}$ & 3.57 & 4.20 & $\mathrm{~B}$ \\
\hline $\begin{array}{l}\text { 19. Peralatan tersedia lengkap dan modern } \\
\text { untuk memudahkan pelayanan di SBA. }\end{array}$ & 3.35 & 4.15 & $\mathrm{~B}$ \\
\hline $\begin{array}{l}\text { 20. Adanya informasi pelayanan atau buku } \\
\text { petunjuk yang tersedia sebagai pedoman } \\
\text { dalam permintaan pelayanan. }\end{array}$ & 2.82 & 3.99 & $\mathrm{C}$ \\
\hline Rata-rata $X$ dan $Y$ & 3.11 & 4.04 & \\
\hline
\end{tabular}

Sumber : Data Primer diolah tahun 2015

Berdasarkan data tabel di atas dapat diketahui nilai perhitungan rata-rata dari penilaian tingkat kepentingan dan kinerja Sub Bagian
Akademik (SBA). Data tabel diatas akan memudahkan penulis dalam memasukkan datanya ke dalam diagram kartesius yang 
terbagi menjadi empat kuadran yaitu A, B, C dan D. Berdasarkan tabel di atas dapat diketahui bahwa rata-rata skor kinerja adalah sebesar 3,01. Sedangkan rata-rata skor kepentingan adalah sebesar 4,04. Titik perpotongan antara sumbu $\mathrm{x}$ dan $\mathrm{y}$ pada diagram kartesius adalah pada perpotongan antara rata-rata skor kinerja dan rata-rata terbagi menjadi empat bidang pada titik koordinat berdasarkan skor rata-rata kinerja dan berdasarkan skor rata-rata harapan. tingkat pelaksanaannya masih dirasakan belum memuaskan oleh penerima layanan. Kategori serv quality yang termasuk dalam kuadran ini adalah:

1. Mahasiswa mendapatkan kemudahan dalam memperoleh akses dan informasi pelayanan

2. Petugas memberlakukan setiap Mahasiswa penerima layanan dengan simpati dan manusiawi

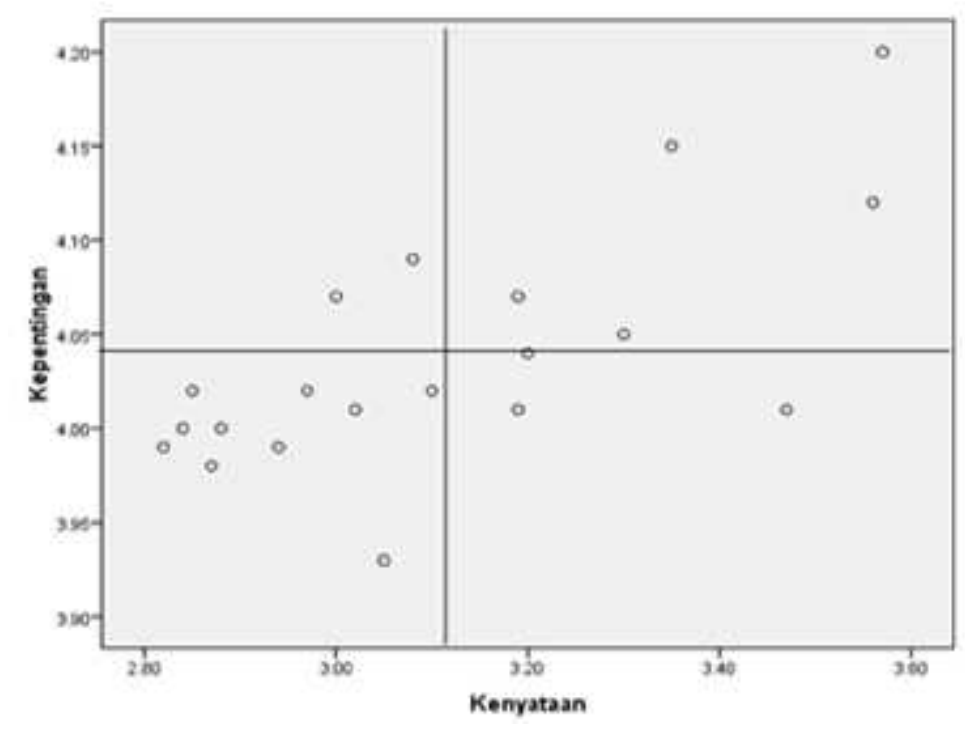

\section{Gambar 2. Diagram Kartesius Pelayanan di SBA Program Vokasi UI}

\section{Kuadran A}

Pada kuadran ini menunjukkan kategori serv quality yang mempengaruhi kepuasan penerima layanan Sub Bagian Akademik. Penangan pada kategori ini perlu diprioritaskan oleh pihak manajemen vokasi , karena keberadaan faktor-faktor ini dinilai sangat penting oleh mahasiswa. Sedangkan

\section{Kuadran B}

Pada kuadran ini menunjukkan kategori serv quality yang mempengaruhi kepuasan penerima layanan Sub Bagian Akademik. Pada kategori ini perlu dipertahankan oleh pihak manajemen vokasi. Keberadaan kategori ini dinilai oleh mahasiswa kinerja pelaksanaannya sudah memuaskan dan sesuai 
dengan harapan. Kategori serv quality yang termasuk dalam kuadran ini adalah:

1. Petugas memenuhi pelayanan yang telah dijanjikan

2. Petugas memberikan informasi yang jelas dan mudah dimengerti atas pertanyaan Mahasiswa

3. Petugas cukup berpengetahuan dan terampil dalam melayani Mahasiswa

4. Petugas SBA memiliki penampilan yang bersih dan rapih

5. Ruang Pelayanan SBA terlihat bersih dan nyaman

6. Peralatan tersedia lengkap dan modern untuk memudahkan pelayanan di SBA

\section{Kuadran C}

Pada kuadran ini menunjukkan kategori serv quality yang mempengaruhi kepuasan mahasiswa terhadap layanan Sub Bagian Akademik(SBA). Kategori serv quality yang masuk dalam kuadran ini dianggap kurang penting oleh mahasiswa, sedangkan kualitas pelaksanaannya relatif biasa saja. Kategori serv quality yang termasuk dalam kuadran ini adalah:

1. Prosedur pelayanan yang ada di SBA mudah dan tidak berbelit-belit

2. Mahasiswa mendapatkan sesuatu yang dibutuhkan dengan cepat

3. Petugas cepat tanggap memahami kebutuhan dan permintaan Mahasiswa

4. Petugas segera bertindak menyelesaikan kebutuhan dan permintaan mahasiswa

5. Kerelaan dan sikap tulus dari petugas untuk membantu Mahasiswa

6. Petugas SBA dapat berkomunikasi secara efektif
7. Petugas mendengarkan dengan seksama keluhan-keluhan atau permintaan Mahasiswa.

8. Petugas mengerti kebutuhan Mahasiswa secara rinci

9. Mahasiswa merasa nyaman dalam mengeluarkan pendapat tentang kebutuhan terhadap petugas layanan

10. Adanya informasi pelayanan atau buku petunjuk yang tersedia sebagai pedoman dalam permintaan pelayanan

\section{Kuadran D}

Pada kuadran ini ini menunjukkan kategori serv quality yang mempengaruhi kepuasan mahasiswa terhadap layanan Sub Bagian Akademik(SBA). Pada kategori serv quality ini mahasiswa menganggap kurang terlalu penting, namun dalam pelaksanaannya telah dilakukan dengan baik oleh petugas SBA, sehingga sangat memuaskan penerima layanan. Kategori serv quality yang termasuk dalam kuadran ini adalah:

1. Petugas SBA memberikan pelayanan secara menyeluruh dan tuntas

2. Petugas SBA percaya diri saat memberikan pelayanan

\section{Simpulan dan Saran}

\subsection{Simpulan}

Berdasarkan hasil penelitian dan pembahasan, dapat disimpulkan sebagai berikut:

1. Bahwa terdapat gap yang cukup besar antara persepsi terhadap kinerja pegawai SBA dengan harapan/kepentingan mahasiswa Program Vokasi UI khususnya mahasiswa bidang Administrasi. Kinerja layanan SBA masih dianggap buruk oleh mahasiswa bidang 
Administrasi.

2. Berdasarkan perhitungan statistik dan diagram kartesius, beberapa hal yang dianggap baik dan perlu dipertahankan adalah: Petugas memenuhi pelayanan yang telah dijanjikan, Petugas memberikan informasi yang jelas dan mudah dimengerti atas pertanyaan Mahasiswa, Petugas cukup berpengetahuan dan terampil dalam melayani Mahasiswa, Petugas SBA memiliki penampilan yang bersih dan rapih, Ruang Pelayanan SBA terlihat bersih dan nyaman serta Peralatan tersedia lengkap dan modern untuk memudahkan pelayanan di SBA.

3. Selain hal itu, terdapat dua hal yang menurut mahasiswa perlu ditingkatkan karena mempunyai tingkat kepentingan yang tinggi. Kedua variable tersebut ialah: Mahasiswa mendapatkan kemudahan dalam memperoleh akses dan informasi pelayanan serta petugas memberlakukan setiap Mahasiswa penerima layanan SBA dengan simpati dan manusiawi.

\subsection{Saran}

Hal yang perlu mendapat perhatian dan perbaikan utama dari pihak Manajemen Program Vokasi UI ialah:

1. Manajemen program vokasi perlu membuat sebuah Standar Operating Prosedur(SOP) tentang bagaimana mendapat pelayanan di Sub Bagian Akademik Program Vokasi UI. sehingga Mahasiswa Vokasi UI khususnya bidang Administrasi tidak merasa kesulitan dalam mengakses informasi layanan.

2. Manajemen program vokasi perlu memberi pelatihan dan motivasi kepada petugas Sub Bagian Akademik(SBA) agar dapat memberlakukan setiap mahasiswa penerima layanan dengan simpati dan manusiawi. Hal ini agar mahasiswa dapat merasa nyaman dengan petugas SBA.

\section{DAFTAR PUSTAKA}

A.Parasuraman, A.Zeithmal, V., \& L.Barry, L. (1988). Communication and Control Processes in the Delivery of Service Quality,. Journal of Marketing, 45.

Arikunto, S. (2003). Prosedur Penelitian. Jakarta: Rineka Cipta.

Dwiyanto, A. (2006). Reformasi Birokrasi Publik. Yogyakarta: Gadjah Mada University Press.

Gasperz, V. (2005). Implementing an ISO 9001:200O And Continual Quality Improvement. Jakarta: PT. Gramedia Pustaka Utama.

Kottler, P. (2000). Marketing Management : Analysis, Planning, Implementation and Control. Englewood Cliff: Prentice-Hall 12ed.

McClave, J. T., Benson, P. G., \& Sincich, T. (2011). Statistik Untuk Bisnis dan Ekonomi. Jakarta: Penerbit Erlangga. 
Ong, J. O., \& Pambudi, J. (2014). Analisis Kepuasan Pelanggan Dengan Importance Performance Analysis Di Sbu Laboratory Cibitung PT Sucofindo (Persero). J@TI Undip, Vol IX, No 1 , 5.

Prasetyo, B., \& Jannah, L. M. (2005). Metode Penelitian Kuantitatif: Teori dan Aplikasi. Jakarta: PT RajaGrafindo Persada.

Santoso, H. (2006). Meningkatkan Kualitas Layanan Industri Jasa Melalui Pendekatan Integrasi Metoda Servqual-Six Sigma Atau Servqual-Qfd. J@TI Undip, 92.

Sugiarto, E. (1999). Psikologi Pelayanan Dalam Industri Jasa. Jakarta: PT Gramedia Pustaka.

Sugiyono. (2009). Metode Penelitian Kuantitatif, Kualitatif dan RछD. Bandung: Alfabeta.

Tjiptono, F. (1998). Manajemen Jasa. Yogyakarta: Andy Offset Edisi 2.

Umar, H. (2002). Metode Riset Bisnis. Jakarta: PT.Gramedia Pustaka Utama.

Wijayanto, B. (2009). Kualitas Pelayanan Publik di Mahkamah Konstitusi. Depok: FISIP UI.

Yustisianto, J. (2007). Analisis Kualitas Pelayanan Kesehatan Studi Kasus Pusat Kesehatan Masyarakat (Puskesmas) Kecamatan Gambir Jakarta Pusat. Depok: FISIP UI.

Zulganef. (2006). Pemodelan Persamaan Struktur dan Aplikasinya menggunakan AMOS 5. : . Bandung: Pustaka. 